\title{
BASIC AND LECTIN HISTOCHEMISTRY OF THE PREGNANT AND NON PREGNANT VAGINAL MUCOSA OF SHE-CAMEL
}

\author{
FAYED, M. H. AND KASSAB, M. \\ DEPARTMENT OF ANATOMY AND HISTOLOGY, FACULTY \\ OF VETERINARY MEDICINE, KAFER EL-SHEIKIH
}

\begin{abstract}
Traditional non-lectin staining methods as periodic acid Schiff (PAS) and Alcian blue at $p H 2.5$ (Ab 2.5), as will as horseradish peroxidase (HRP) conjugated Helix pomatia agglutinin (HPA) and Girffonia simplicifolia agglutinin(GSA-1)were used to investigate the pregnancy associated changes on the vaginal mucosa of She-camel. There was remarkable increase in the glycoproteins(GPs) with oxidizable vicinal dioles in the upper most layer of the vaginal epithelium of the pregnant She-camel. At the same time, only little increase in the GPs with carboxyl group and/or with O-sulfate ester was limited to the goblet cells of the vaginal mucosa. Significant changes could be detected in the lectin histochemistry in pregnant She-camel comparing with the non-pregnant one.Abundant amount of $N$-acetylgalactosamine detected in the plasmalemma of all layers of the vaginal mucosa of She-camel especially in the mucous secreting cells. The changes of D-galactos and/or $N$-acetylgalactosamine were restricted to the goblet cells.
\end{abstract}

Key wards Glycoprotein; Lectin; histochemistry; Camel, Vagina.

\section{INTRODUCTION}

The non-pregnant vaginal epithelium undergoes estrous cyclerelated changes. Of these changes, increase in the thickening of the epithelium from seven layers in quiescent diestrous phase to eleven layers in the late proestrous (Putti and Varano 1979 and Nelson et al., 1982); the two superficial layers of the epithelium transdifferentiate from squamous into mucinous cells (Walker 1960); abundant cornification is occurred in estrous and desquamation of the stratified squamous epithelium in metestrous (Vircic et al., 1991). These changes in cell morphological structure are accompanied by the changes in the carbohydrate residues, which recognized by lectin histochemistry (Vircic et al., 1991). 
At pregnancy, the vaginal epithelium becomes thinner than at any other phases of non-pregnancy (Ghannam, et al., 1972 and Richardson 1972). It reached to 3 - 4 layers in pregnant ewes and cows (Ghannam 1974 and Fatoh 1978). The mucous filled cells in the superficial layers of the vaginal epithelium become more abundant (Warren and Spicer 1961). Wu et al., 1983 and Lee et al., 1983 showed that, lectin can be used to study cell surface changes associated with pregnancy in all parts of the female genital tract including endometrial gland, oviductal cells, cervix and vagina. Lee and Damjanov 1985 showed that, in pregnancy, the endometrial glands exhibit increased binding of lectins specifying terminal galactose residues and lectin specifying $\mathrm{N}$-acetylgalactosamine, whereas the fucos specifying lectins are completely lost. These changes reflect other functional and structural cell surface alteration associated with pregnancy (Glasser 1972).

In order to establish whether the vaginal mucosa of the she-camel that undergoes pregnancy-related changes or not, we compared the reactivity of non-pregnant vagina with the reactivity of pregnant one using PAS, Ab 2.5,HRP/HPA and HRP/GSA-1 as histochemical markers.

\section{MATERIALS AND METHODS}

\section{Samples collection and tissue preparation:}

The samples were collected from 6 camels at Kom Hamada, Cairo and Pelpees abattoir. Of these animals, three were pregnant and three were non-pregnant. A pieces of tissue were rapidly removed after slaughtering and fixed in 10\% neutral buffered formaldehyde solution ( $\mathrm{pH} 7.4$ ) at room temperature for 24 hours.After that, the samples were thoroughly rinsed in phosphate buffer ( $\mathrm{pH}$ 7.4) dehydrated in series of increasingly concentrated ethanol, cleared in xylen and embedded in paraffin wax. Sections of 4-6 $\mu \mathrm{m}$ thickness were mounted on albumen coated slides.

\section{Staining techniques:}

\section{Morphological and basic staining:}

The slides were deparafinized in xylen and stained with Gill's heamatoxylin (Gill et al., 1974) and eosin (H \& E) for histological assessment. Other sections were subjected to the histochemical Kafr El-Sheikh Vet. Med. J. Vol. 2 No. 1 (2004) 
procedures, including PAS for GPs with oxidizable vicinal dioles and AB 2.5 for GPs with carboxyl group and/or with O-sulfate ester (Bancroft and Stevens 1996).

\section{Lectin staining:}

The staining procedures with the lectins were similar to that described by Schulte and Spicer, (1983), Bancroft and Stevens (1996) and Rhodes and Milton (1998). Briefly, after hydration, the sections were treated with $0.3 \%$ hydrogen peroxide (H2O2) for blocking of the endogenous peroxidase enzyme, rinsed in distilled water and washed in $1 \%$ bovine serum albumen (BSA) in $0.1 \mathrm{M}$ phosphate buffered saline (PBS) $\mathrm{pH}$ 7.4. The sections were then incubated for 12 hours at $4{ }^{\circ} \mathrm{C}$ in HRP conjugated lectins dissolved in $0.1 \mathrm{M}$ PBS pH 7.4 (contain $0.1 \mathrm{M}$ $\mathrm{NaCl} 2,0.1 \mathrm{mM} \mathrm{CaCl} 2, \mathrm{MgCl} 2, \mathrm{MnCl} 2)$ and then rinsed three times in PBS. The optimal concentration for each lectin (Sigma Chemical Co. St Louis, MO, USA) which allowed maximum staining with minimum background was as follows: GSA-1 $100 \mu / \mathrm{ml}$ and HPA $6 \mu / \mathrm{ml}$. Visualizing of the sites containing bound lectin-HRP was obtained by incubating the slides with PBS, containing 3,3' diaminobenzidine tetrahydrochloride (DAB) (25 mg / $100 \mathrm{ml}$ ) and $0.003 \% \mathrm{H} 2 \mathrm{O} 2$, for 10 minute at room temperature. Specimens were rinsed in distilled water, dehydrated using graded ethanol, cleared in xylen and mounted in DPX.

For chemical control purpose of the lectin staining, the following steps were done:

1- The HRP conjugated lectins were substituted by unconjugated lectins.

2-The slides were exposed to HRP medium without lectins.

$3-O x i d a t i o n$ with $1 \%$ periodic acid for 10 minute prior to HRP-lectin staining.

4-Incubation of the slides with the corresponding haptten sugars inhibitor for each lectin before staining. The haptten sugars inhibitors were employed from $0.05 \mathrm{M}$ to $1 \mathrm{M}$ but complete elimination of the staining was obtained at $0.2 \mathrm{M}$. 


\section{RESULTS}

\section{Histology:}

The vaginal epithelium was stratified columnar epithelium consists of 4-6 layers in non-pregnant animal while it was about 5-7 layers in pregnant one.The upper most layer of the non-pregnant vaginal epithelium contained few goblet cells while in pregnant one, the goblet cells were more abundant (fig.1, 2, 3 \& 4). The lamina propria submucosa was dense irregular connective tissue contained fibroblasts, macrophages and lymphocytes in non pregnant vagina but in pregnant one, it was loosely adhered, highly vascular connective tissue contained aggregation of macrophages and lymphocytes in the form of lymph nodules (fig $1 \& 2$ ). The stratified epithelium of the pregnant vagina showed migrating lymphocytes and leukocytes (fig. 3) more than that in non-pregnant one(fig.4).

\section{Histochemical staining:}

\section{A-Basic carbohydrates histochemistry:}

The uppermost layer of the pregnant vaginal epithelium was PASpositive, in the supranuclear region with some secretion protruded from the apical part as apocrine secretion while the remaining layers were PAS-negative (fig.5). In the non-pregnant vagina, only small protrusion or plebes were PAS- positive on the apical surface of the epithelium (fig.6).

In non pregnant vaginal epithelium only the apical part of the upper cell layer show Ab 2.5 positive reaction with plebes like structure while in the pregnant one the positive reaction was restricted only to the goblet cells (figs.7 \& 8).

\section{B- Lectin histochemistry:}

\section{Helixpomatia agglutinin (HPA):}

In non-pregnant she-camel, the HPA reactive sites were restricted to the basal and the upper two layers of the vaginal epithelium while the rest of the layers were negative. In the basal layer, the reaction was limited mainly to the cell lateral boundaries while in the two uppermost 
layers, the reaction was strong in the lateral boundaries and apical membrane with some secretions over the epithelium (figs. 9 \&10). Feeble reaction was detected in the cytoplasm of both apical and basal layers (fig.10). The propria submucosa was negative to HPA except the strong reaction of the intema of the blood vessels (fig.9).

The vaginal epithelium of the pregnant she-camel showed overall intense reaction with HPA comparing with that in non-pregnant one (figs. 9,10,11\&12). The intensity of the reaction was varied between the sides of the mucosal folds and the surface epithelium. In the sides of the folds, the reaction was strong in the cell boundaries of the basal layers, disappeared from the other layers except the strong reaction of the goblet cells. Inspit of the boundaries of the goblet cells showed negative reaction the globules and the apical cell membrane were very strong in it's reaction with some secretion extruded to the lumen (fig.12). On the other hand, the surface epithelium of the pregnant she-camel was characteristics in it's reaction. The cell boundaries of all layers were strongly reacted. The apical layer showed darkly stained goblet cells (fig.13).

As in non-pregnant, the lamina propria submucosa was negative except the intema of the blood vessels (fig.11)

\section{Girffonia simplisifolia agglutinin (GSA-1):}

Generally, the reactivity of the vaginal epithelium of the she camel in both pregnant and non-pregnant with GSA-1 was less than that with HPA.

In non-pregnant she camel, the reaction found only in the apical surface of the superficial layer as blebs of secretion while the remainder of the epithelial layers and the lamina propria was negative (fig 14).

In pregnant she-camel, the reaction was limited only to the mucous globules of the goblet cells found in the apical layer. The other layers of the epithelium and lamina propria submucosa were negative to GSA - 1 (figs 15 \& 16). 


\section{DISCUSSION}

In the present study, the vagina was differing in thickness during pregnant and non-pregnant she-camel.It was stratified columnar epithelium formed from 3 - 4 layers in non-pregnant and 5 - 7 layers in pregnant one. Richardson (1972), Fatoh (1978) and Ghannam (1974) stated that the vagina of ewe becomes thinner and stratified squamous non-keratinized during pregnancy. This contradiction with the present results could be explained on the basis of species variation, as the gestation period in shecamel extended to 407 days while it is only 150 days in ewe.

Our results revealed the existence of GPs with oxidizable vicinal dioles restricted to the upper most layers either in pregnant and nonpregnant she camel. It was more pronounced in pregnant than in nonpregnant animal. This is not similar to that found in ewes by Fatoh (1978) who described it in all layers of vaginal epithelium, and that reported by Stienbach and Smidt (1970) in sow, who describe it in the basal layer only.

The GPs with carboxyl group and/or with O-sulfate ester was less predominant than that with oxidizable vicinal dioles. It was more in pregnant than in non-pregnant vaginal epithelium. The GPs with carboxyl group and/or with O-sulfate ester was restricted to the goblet cells in pregnant and to the upper part of the cells of the apical layer in nonpregnant animals. These results coincide with Sunderavadanou (1976) in buffaloes. The latter author attribute these result to the fact that, only the upper most layers of the epithelium are secretory in function. On the other hand, Fatoh (1978) in ewes clarified that; the acid mucopolysaccharides are present in the stratum corneum and upper one or two layers of the stratum spinosum of the vaginal epithelium of ewe.

The increased amount of GPs with oxidizable vicinal dioles and GPs with carboxyl group and/or with O-sulfate ester in the vagina of shecamel during pregnancy could explain on the basis of influence of progesterone. These explanations coincide with Jones and Edgren (1973), who found that, norgestrel, and synthetic progesterone can induce mucinous transformation of the surface epithelium of the vaginal mucosa. The same cyclic changes occurred in human as well (Sjoberg et al. 1988).

Kafr El-Sheikh Vet. Med. J. Vol. 2 No. 1 (2004) 
The results of the present study is in agreement with the results of Warren and Spicer (1961) who found that, changes in the sialic acid level in the vagina during the estrous cycle occurred parallel with the cyclic variation of the amount of mucin observed histochemically. Both sialic acid and amount of mucin are elevated in pregnancy Warren and Spicer (1961).

The obtained result revealed that $\alpha$-D-galactose and N-acetylgalactosamine described by HPA and GSA-1 labeled lectins were more pronounced in pregnant than in non-pregnant animals. The GSA-1 positive glycoconjugates observed in the goblet cells of pregnant vagina and in the apical part of cells of the superficial layer in non-pregnant one. $\mathbf{W u}$ et al. (1983) described strong GSA-1 reactivity in cervix and vagina of nonpregnant mice, while in pregnant animal, it was confined to the endometrium. The deference could be attributed to the species in which the terminal sugar is not similar.

The HPA positive glycoconjugates was more pronounced in the plasmalemma of epithelial layers and in the goblet cells in pregnant animal.In non-pregnant animals, the reaction confined to the plasmalemma of the basal and superficial two layers only. Vircic et al. (1991) found that, some lectins as GSA-I, GSA-II, HPA Vicia vilosa agglutinin (VFA) reacted exclusively with the apical mucinous cells and other lectins as Triticum vulgare agglutinin (WGA), Ricinus communis -1 (RCA-I) reacted also with the underlying layers. he suggested that the expression of glycoconjugates fluctuates quantitatively during the estrous cycle and pregnancy.

The presence of terminal galactose rich glycoprotein were identified that were maximally expressed in the estrus phase of non-pregnant endometrium and also those that had peak expression in pregnancy. RCA-I, Ricinus communis agglutinin -11 (RCA-II) and Cytisus scoparius (CSA) (Horvat, 1993). The presence of $\mathrm{N}$ - acetyl galactosamine at the cells boundaries in either pregnant and non-pregnant epithelium of the vagina 
is an indicative of a role of these molecules in the regulation of movements of ions and fluid (Spicer and Schulte 1992).

Our results showed that, the endothelial layer of the tunica intima of the blood vessels was reacted to the HPA, it was more in the small blood vessels of the pregnant she-camel vagina, the same results were observed by Sgambati et al. (2002) in the placenta of human and concluded that, the presence of these sugars residues in endothelial cells may indicate their role for normal proliferation and branching of the vessels and for adequate membrane permeability and cellular metabolism.

\section{LEGENDS}

Fig. (1): Pregnant vagina of she-camel showing, the epithelium (E), loosely adhered connective tissue of propria submucosa (P) and lymphatic nodule (L). H\&E, X 100

Fig. (2): Non-pregnant vagina of she-camel showing, epithelium (E), dense connective tissue of propria-submucosa (P). H\&E, X 400

Fig. (3): High magnifications of fig 1, showing stratified columnar epithelium (E), goblet cells (G), migrating lymphocyte (open arrowhead). H \& E, X 1000.

Fig. (4): High magnifications of fig 2, showing stratified columnar epithelium (E), goblet cells (G), migrating lymphocyte (open arrowhead). H \& E, X 1000.

Fig. (5): Pregnant vagina of she-camel showing stratified columnar epithelium (E), PAS positive material (solid arrowhead), and propria-submucosa (P). PAS, X 400.

Fig. (6): Non-pregnant vagina of she-camel showing stratified columnar epithelium (E), PAS positive material (solid arrowhead), and propriasubmucosa (P). PAS, X 400.

Fig. (7): Pregnant vagina of she-camel showing stratified columnar epithelium (E),AB 2.5 positive material in goblet cells( $G$ ) of the apical cell layer (solid arrowhead), AB 2.5, X 400. 
Fig. (8): Pregnant vagina of she-camel showing stratified columnar epithelium (E), AB 2.5 positive material in goblet cells $(G)$ of the apical cell layer (solid arrowhead) and negative propria submucosa (P). AB 2.5, X 400 .

Fig. (9): Non-pregnant vagina of she-camel showing reacting epithelium (E), negative propria submucosa $(\mathrm{P})$, and positive blood vessels $(\mathrm{V})$. HPA X 400.

Fig. (10): High magnification to fig 9, showing HPA positive basal layer (B), positive boundaries of the apical layer (A) and negative other layers (R), negative propria submucosa (P). HPA X1000.

Fig. (11): Pregnant vagina of she-camel showing reacted epithelium(E),negative propria submucosa $(\mathrm{P})$, positive intema of small blood vessels (V). HPA X 100.

Fig. (12): Pregnant vagina of she-camel at the sides of mucosal fold showing HPA positive boundaries at the basal layer (B), positive goblet cells (G) of the apical layer (A), negative other layers(R). HPA X 1000.

Fig. (13): Pregnant vagina of she-camel at the surface epithelium showing HPA positive boundaries to all layers of epithelium (E), darkly stained goblet cells (solid arrowhead). HPA X 1000.

Fig. (14): Non-pregnant vagina of she-camel showing GSA-1 negative epithelium (E), positive blebs like structure at the apical part of the cells (solid arrowhead), negative propria submucosa (P). BSA-1 X 400.

Fig (15): Pregnant vagina of she-camel showing GSA-1 positive goblet cells $(\mathrm{G})$, negative epithelium (E), negative propria submucosa (P). BSA1 X 400 .

Fig (16): High magnifications of fig 15, showing GSA-1 positive goblet cells with its mucous globule(G), negative epithelium(E).BSA-1 X 1000. 
FAYED, M. H.., et.al.

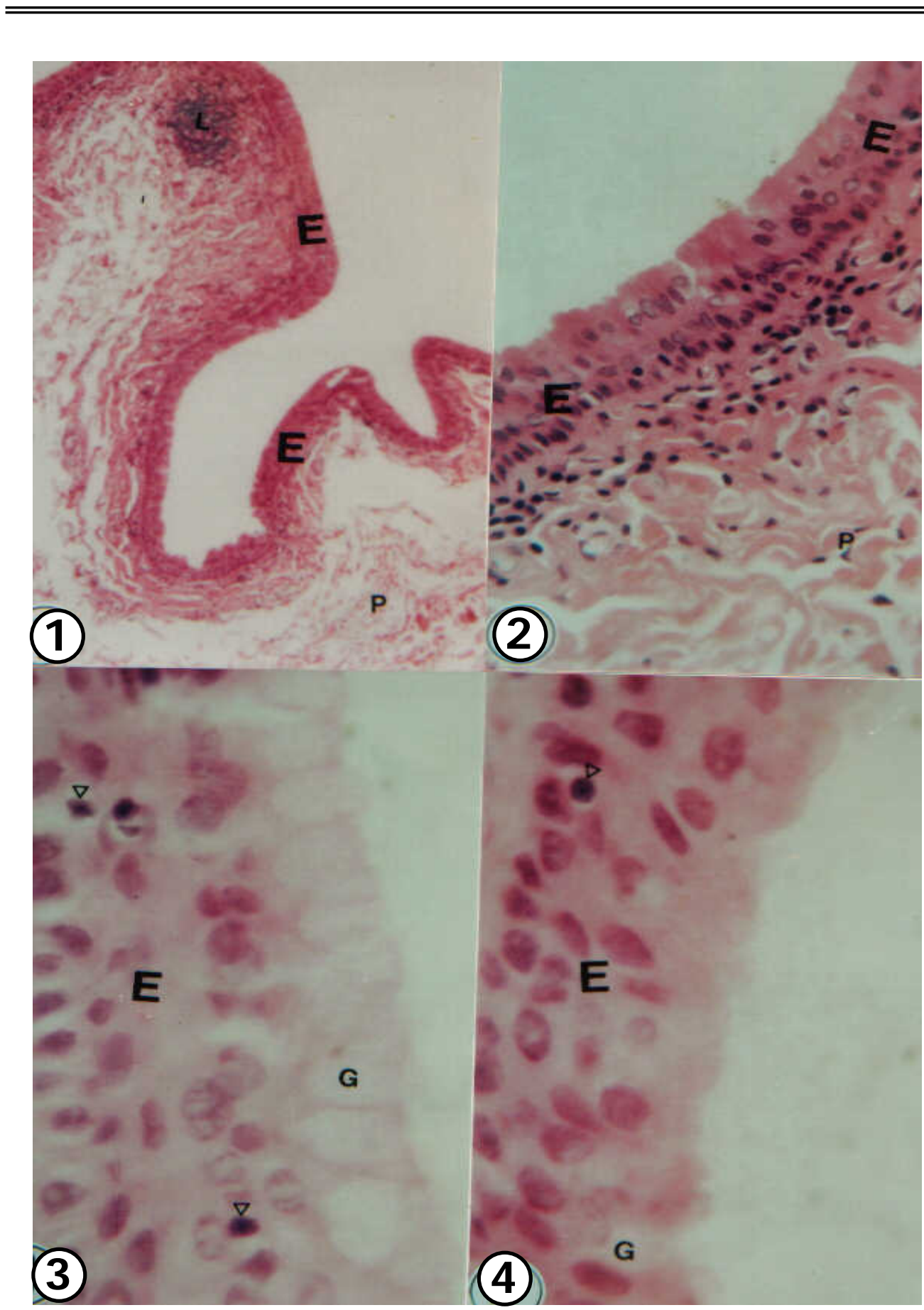

$\overline{\overline{\text { Kafr El-Sheikh Vet. Med. J. Vol. } 2 \text { No. } 1 \text { (2004) }}}$ 


\section{Basic And Lectin Histochemistry Of The Pregnant And Non ...}

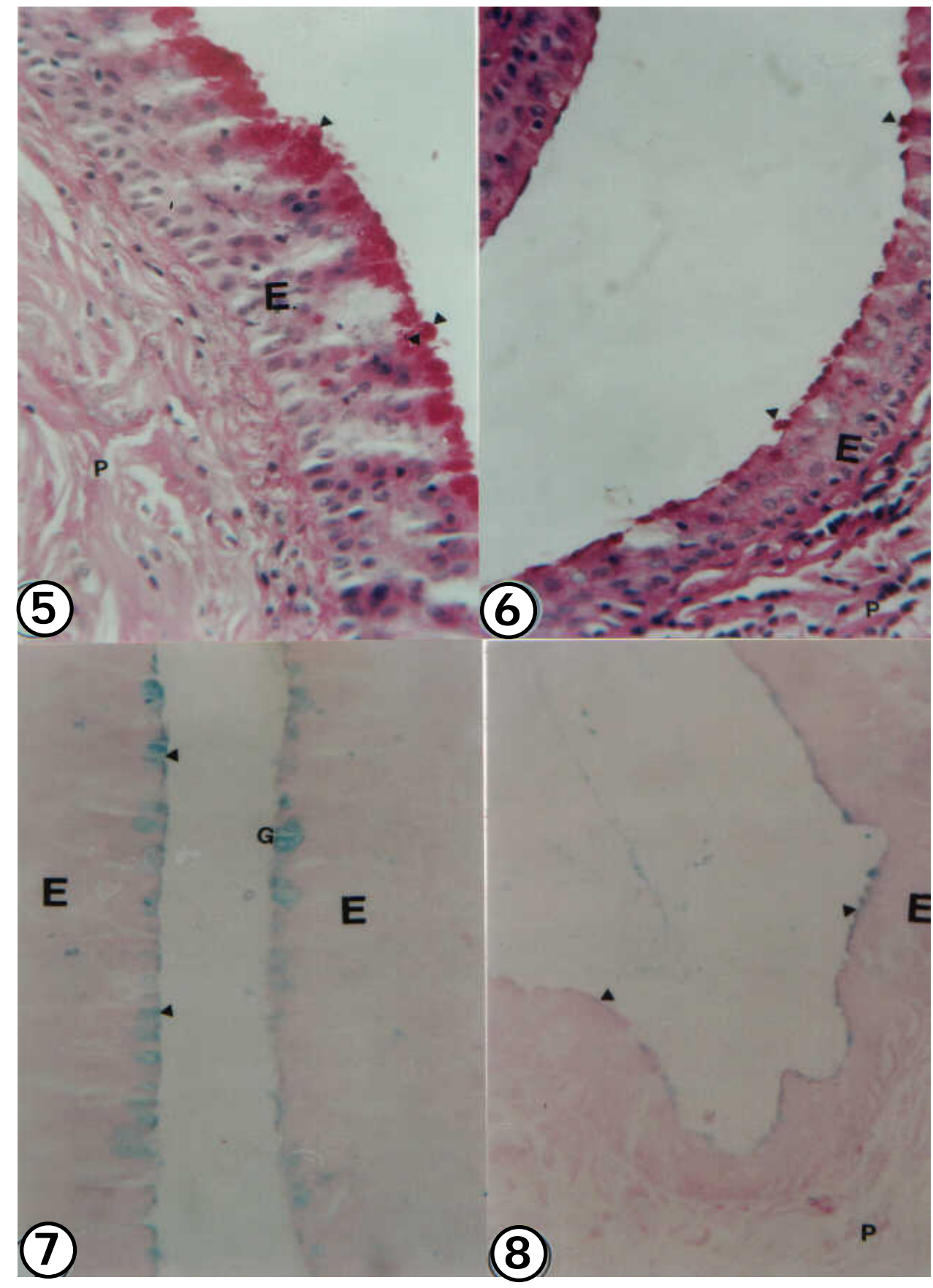

$\overline{\text { Kafr El-Sheikh Vet. Med. J. Vol. } 2 \text { No. } 1 \text { (2004) }}$ 
FAYED, M. H.., et.al.

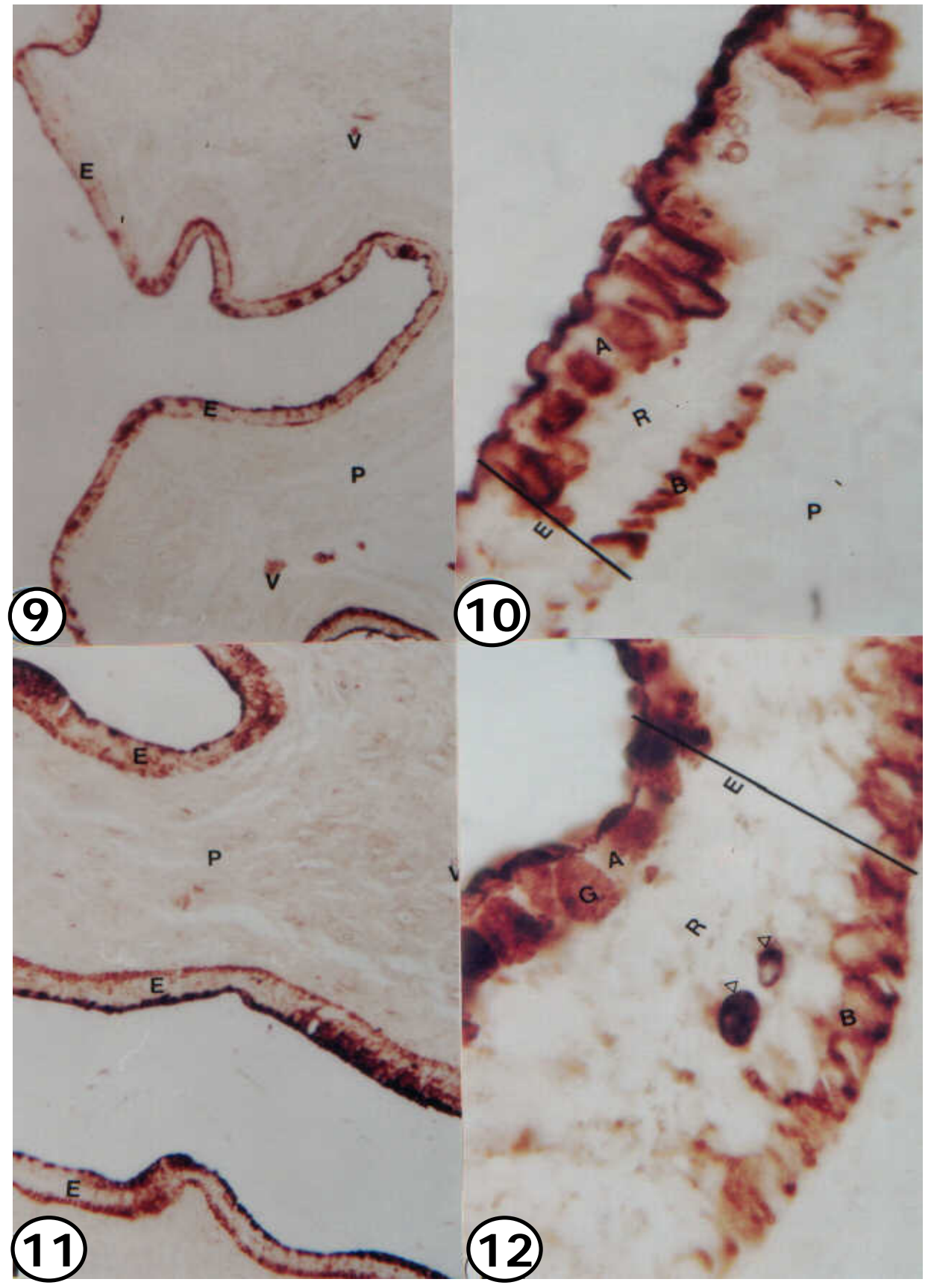

$\overline{\text { Kafr El-Sheikh Vet. Med. J. Vol. } 2 \text { No. } 1 \text { (2004) }}$ 
Basic And Lectin Histochemistry Of The Pregnant And Non ...

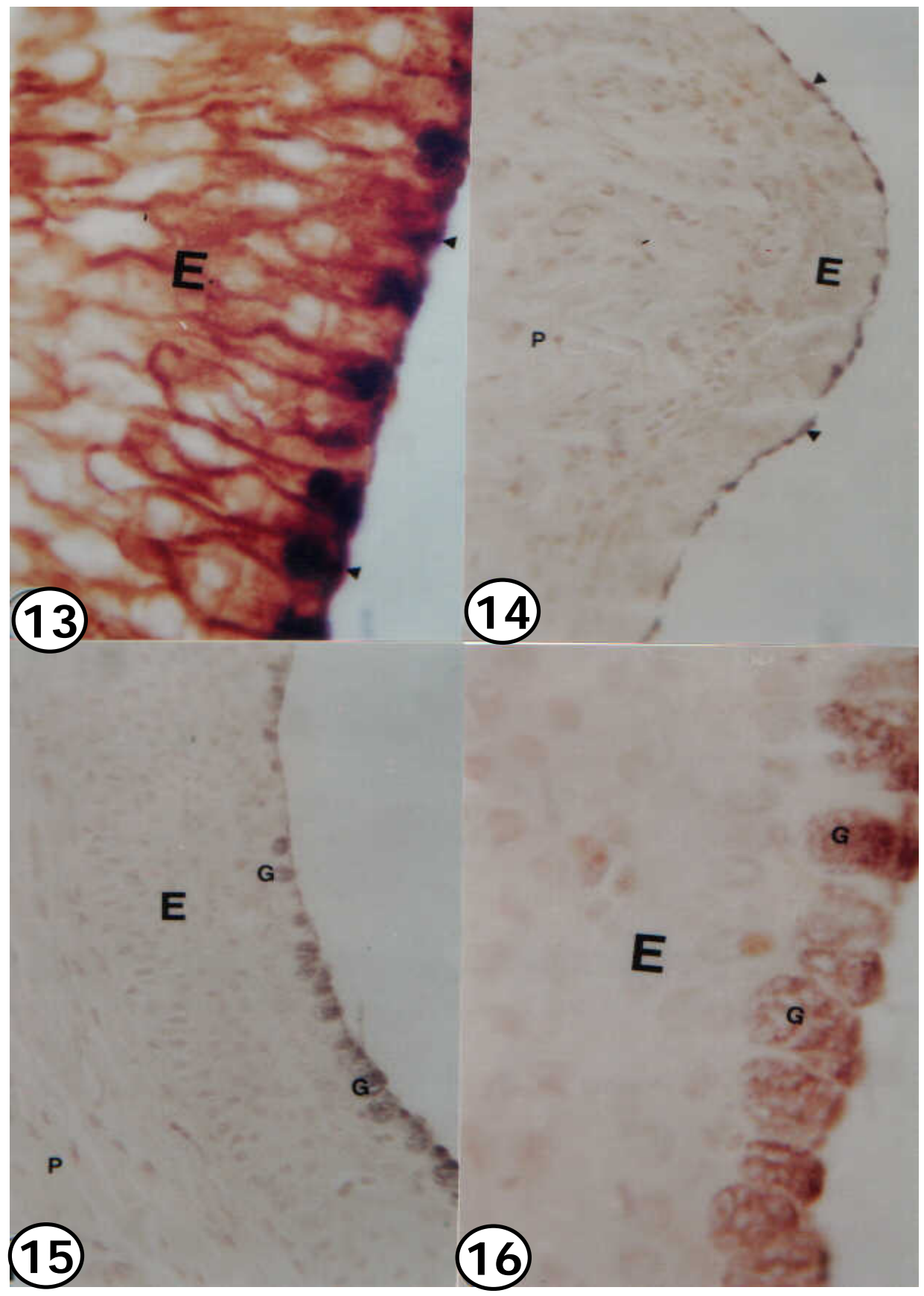

$\overline{\overline{\text { Kafr El-Sheikh Vet. Med. J. Vol. } 2 \text { No. } 1 \text { (2004) }}}$ 


\section{REFERENCES}

- Bancroft, J. D. and Stevens A. (1996): Theory and practice of histological technique. Churchill, Livingstone, Edinburg, London.

- Fatoh, M. (1978): Histological and 'histochemical changes occurring in the vagina of osimi ewes during the estrous cycle and pregnancy. M. V. Sc., Obest. Gyna. And A. I. Dep., Fac. Vet. Med., Cairo Univ.

- Ghannam, S. M.; Bosc, M. J. and Buisson, F. (1972): Examination of the vaginal epithelium of the sheep and its use in pregnancy diagnosis. Amer. J. Vet. Res., 33 (6): 1175.

- Ghannam, S. M. (1974): The epithelia of the anterior part of the vagina in sheep. Egypt. Vet. Med. Ass, 34:113

- Gill, G. W.; Frost, J. and Miller, K. A. (1974): A new formula for half-oxidized hematoxyline solutions that neither over stains nor requires differentiation. Acta Cytol. 18; $300-311$

- Glasser, S. R. (1972): The uterine environment in implantation and decidualization. In: Balin, H.; Glasser, S. (Eds.) Reproductive biology. Excerpta, Amsterdam, PP 776 - 833.

- Horvat, B. (1993): Galactose-binding lectins as markers of pregnancy related glycoprotein. Histochemistry, 99 (1): 95 - 101.

- Jones, R. c. and Edgren, R. a., (1973): The effect of various steroids on the vaginal histology in rat. Fertility and sterility, 24: 284 $-292$.

- Lee, M. C. and Damjanov, I. (1985): Pregnancy- related changes in the human endometrium revealed by lectin histochemistry. Histochemistry, 82: 275-280.

- Lee, M. C.; Wu, T. C.; Wan, Y. J.; Damjanov (1983): Pregnancyrelated changes in the mouse oviduct and uterus revealed differential binding of fluoresceinated lectins. Histochemistry 79; 365 - 375.

- Nelson, J. F.; Felcio, L. S.; Randall, P. K. and Finch, C. E. (1982): Long-itudinal study of estrus cyclicity in aging mice.1-cycle frequency, length and vaginal cytology. Biol. Reprod. 27: 327-334.

$\overline{\overline{\text { Kafr El-Sheikh Vet. Med. J. Vol. } 2 \text { No. } 1 \text { (2004) }}}$ 
- Putti, R. and varano, L. (1979): Histological and histochemical modifica-tions of the uterine and vaginal mucosa of the mouse during the estrus cycle. Basic appl. Histochem. 23: 25 - 32.

- Richardson, C. (1972): Diagnosis of pregnancy in ewe by vaginal biopsy. Br. Vet. J., 128:316

- Rhodes, J. and Milton, J. (1998): Lectin methods and protocols. 1st Ed. Humana Press. Totowa, New Jersey.

- Schulte, B. and Spicer, S. S. (1983): Light microscopic histochemical detection of terminal galactos and $\mathrm{N}$ acetylgalactosamine residues in rodent complex carbohydrates using a galactos oxidase-Schiff sequence and peanut lectin-horseradish peroxidase conjugates. J.Histochem. Cytochem. 31;19-24.

- Sgambati, E., Biagiotti R., Marini M. and Brizzi E. (2002): Lectin histoc-hemistry in the human placenta of pregnancies complicated by intrauterine growth retardation based on absent or reversed diastolic flow, Placenta, 23, 503 - 515.

- Sjoberg, I. Cajander, S. and Rylander, E. (1988): Morphometric charact-eristic of the vaginal epithelium during the menstrual cycle. Gynecol Obestet Invest, 26: 136 - 142.

- Spicer, S. S. and Schulte, B. (1992): Diversity of cell glycoconjugates shown histochemically: aprespective. J. Histochem. Cytochem. 40; 1- 38.

- Steinbach, j.and Smidt,d.(1970): Cyclical phenomena in the female genital tract of swine, histological observation. J. Anim. Sci., 30: 573.

- Sundaravadanau, V. K. (1976): Histology and histochemistry of bovine cervix and vagina. Indian J. Anim. Sci., 44(6): 366.

- Vircic, H.; Horvat, B. and Damjanov, I. (1991): Lectin histochemistry of the vagina of mouse during the estrous cycle. J. Histochem. Cytochem., 39 (12): 1685-1692.

- Walker, b. E. (1996): Renewal of cell populations in the female mouse. Am J. Anat. 107: 95 - 101. 
- Warren, L. and Spicer, S. S. (1961): Biochemical and histochemical identification of sialic acid containing mucins of rodent vagina and salivary gland. J. Histochem. Cytochem., 9: 400-408.

- Wu, T. C.; Wan, Y. J. and Damjanov, I. (1983): Distribution of Banderia Simplicifolia lectin binding sites in the genital organs of female and male mice. Histochemistry, 77: 233-241. 